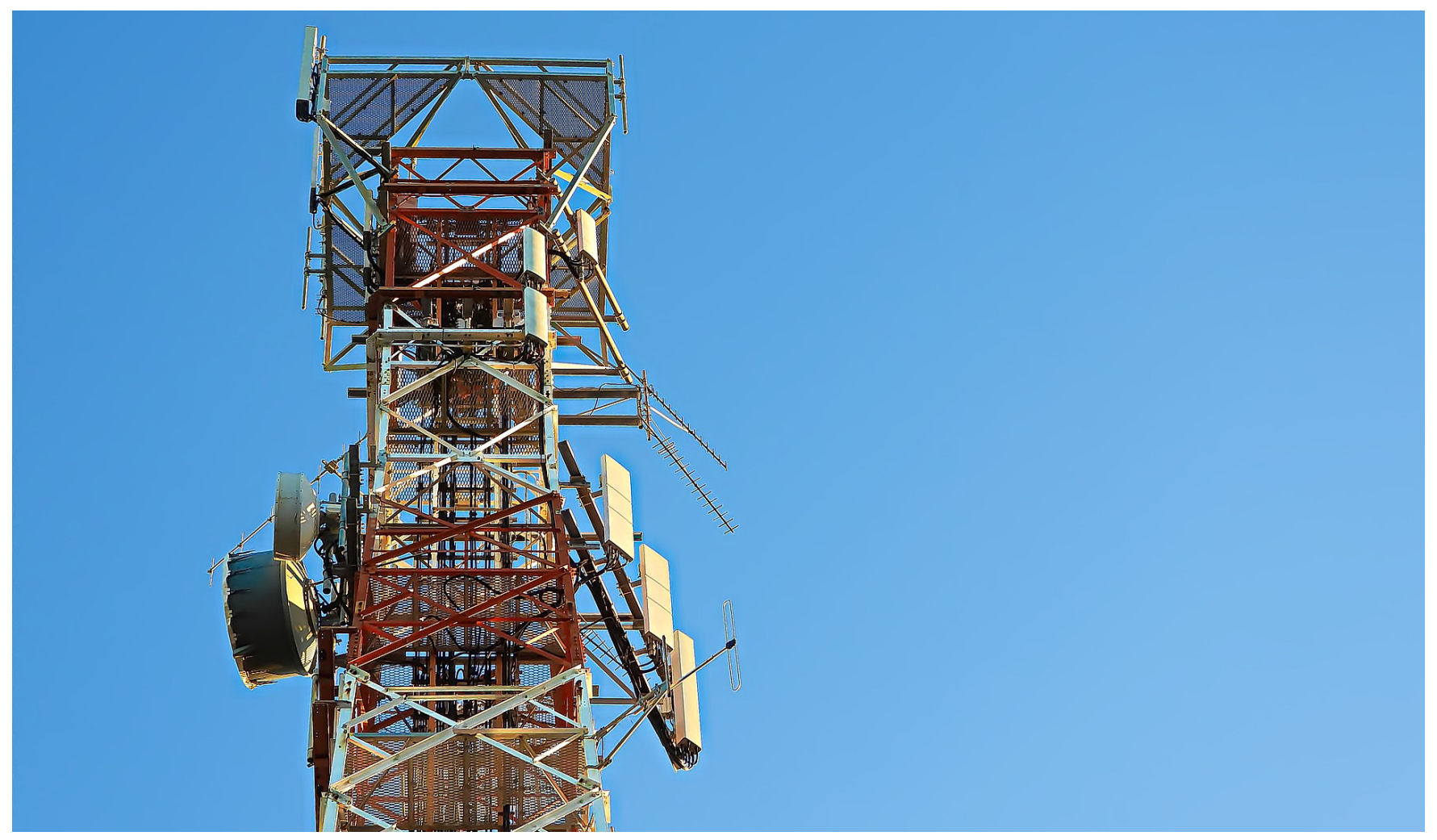

\title{
Beacon Control System within a body of water
}

\section{El sistema de control del faro dentro de un cuerpo de agua}

Fabio Pérez-Márquez

Magister en Administración de Datacenters, Fabio.perez@tecnar.edu.co, Orcid: 0000-0003-2573-7589, Docente Investigador, Fundación Tecnológica

Antonio de Arevalo - Unitecnar, Cartagena de Indias, Colombia. 
Cómo citar: F. Perez-Marquez, "Beacon Control System within a body of water", Sostenibilidad, Tecnología y Humanismo, vol. 10, no. 1, 15-26, 2019.

Resumen

Enestedocumentosediscutelaimplementación de un sistema de comunicaciones inalámbricas para monitorear y controlar las boyas del canal de acceso, ya que en Colombia en la parte costera tiene la bendición de tener acceso a dos océanos que controlan una valiosa fuente de comunicación y transporte con todo el mundo, los recursos y transformaciones marítimas, de tal manera que se han creado estrategias para convertir los océanos de manera óptima y sostenible en fuentes esenciales de desarrollo económico y social, y para proteger la protección, la integración y el progreso marítimo nacional que también permite impactar las zonas costeras, donde se encuentran algunos de los municipios más pobres del país. De esta manera se desea implementar un sistema de comunicaciones que vigile constantemente el funcionamiento delos dispositivos donde serealizala simulación de una red en malla mediante transmisores ZigBee que tiene la capacidad de transmitir y recibir señal inalámbrica en una frecuencia de $2,4 \mathrm{GHz}$ a 1200 metros de la línea de visión en condiciones ideales de trabajo. Zigbee es una tecnología que permite el despliegue de redes inalámbricas basadas en soluciones de bajo costo y consumo, el objetivo principal es la seguridad de las comunicaciones con baja tasa de envío y cambia la vida de sus baterías.

Palabras clave: sistema de comunicaciones, inalámbrico, tecnología, boyas, navegable.

\section{Abstract}

This document discusses the implementation of a wireless communications system to monitor and control the buoys of the access channel, since in Colombia in the coastal part it has the blessing to have access to two oceans that control a valuable source of communication and transport with the whole world, maritime resources and transformations, in such a way that strategies have been created to convert the oceans in an optimal and sustainable way into essential sources of economic and social development, and to protect protection, integration and the national maritime progress that also allows to impact coastal areas, where some of the poorest municipalities in the country are located. In this way it is desired to implement a communications system that will keep a constant watch on the operation of the devices where the simulation of a mesh network is performed using ZigBee transmitters that has the ability to transmit and receive wireless signal at a frequency of $2.4 \mathrm{GHz}$ at 1200 meters to the line of sight in ideal working conditions. Zigbee is a technology that allows the deployment of wireless networks based on solutions of low cost and consumption, the main objective is secure communications with low shipping rate and changes the life of your batteries.

Keywords: system the communications, wireless, technology, buoys, navigable. 
Introduction

Given the geographical position of the city of Cartagena on the Caribbean Sea, according to [1] Cartagena is built in one of the most important seaports in Colombia, its industrial area and the large influx of tourists; This has led to a significant increase in maritime traffic on its access channel. In addition, maritime signaling systems are governed by the IALA standard, which is in charge of regulating and ordering the signaling of navigable channels with beacons at sea, which require rigorous controls to guarantee their continuous operation.

Radio frequency is used in various fields, in the field of aesthetics it is used as a skin care treatment, in mobile communications; It has different uses although the operation is the same, in what differs is in the results it generates. Currently the use of radio frequency communication systems has become widespread and its applications include air traffic control, sea and river navigation, voice, data and video transmission, among other applications [2-4].

Zigbee technology has been found, as Vera [5] explain zigbee technology; It is a low transfer rate, low power consumption wireless technology. The IEEE (Institute of Electrical and ElectronicsEngineers)andZigbeeinpartnership have been working closely together to specify the entire protocol stack in an innovative way of exercising control over different industrial processes. Since this solution is for secure and successful wireless communications with low cost and energy consumption.

The world of today is changing and there are new demands, as reflected by [6] "a highly complex world like the current one expresses a deep crisis", therefore, new ways of creating and doing things are emerging guided for the technical and technological elements that allow the entire paradigm of educational work to change after the execution of new teaching methods and strategies linked to technological tools and orienting them more to the productive world, trying to bring the student closer to their professional work.

\section{General characteristics}

All part of the little information that is available in the beacon status control center, since these are distributed in the access channel to the Bay of Cartagena, and not all are visible from the control center, for example buoy No. 1 is the farthest, and is approximately $18 \mathrm{~km}$ from the control center, so that if the buoy lighting system fails or disengages from its base, it is loose and adrift, made of that the control center only finds out when a boat notices and reports what has happened. It is of great importance to keep the aid in good working order to guarantee the safety of the traffic of the boats at night. [7]. The naval cadet school has presented a prototype for oceanographic measurement with its own technology, the knowledge of this procedure is to measure variations in the coastline, spill of chemical products, precise and exact location of castaways, reproduction of marine species and their migration and lastly I forecast the routes of the hurricanes or storms [8-9]. As for the lighting equipment of a buoy it consists of several components, such as: an electronic card that manages the control logic of the device and where the bulb and its power system such as the solar panel, battery and optional peripherals such as a transceiver are connected monitoring and control and a GPS receiver for synchronization on and off between them. The above are the variables that you want to monitor in order to guarantee the proper functioning of the buoy, since most of the failures in the system are caused by damage to the bulb, discharged battery, solar panel without generation or with the diode Damaged bypass [10-12]. 
Wireless standards that are implemented in today's factories to access services or connect equipment and accessories include $\mathrm{Wi}-\mathrm{Fi}$, Bluetooth, Bluetooth low energy, ZigBee and Near-Field Communication (NFC). Each of these standards has its pros and cons, which must be defined to the types of roles are appropriate. The technologies that stand out are bluetooth and Zigbee which are shortrange and wireless technology and these technologies have been booming in the industrial sector thanks to their low cost and their excellent ability to offer mesh or longdistance communications. squares. Of course, when the mesh is implemented, bluetooth must be implemented, and it is created to be implemented to achieve direct point-to-point communication between devices or point-tomultipoint links [13-14].

"The need to detect and determine what the intangible elements would be that would allow the evolution of knowledge", according to this premise, it should be noted that with the imminent evolution and the use of new technological advances such as networks lowcost and high-range wireless since the use of Information and Communication Technologies is a mechanism that drives and develops the activities of the industry [15].

\section{Methodology}

The research is framed within what defines an experimental quantitative field research and the quantitative research is oriented to measure variables based on a certain magnitude, extension or quantity, where the magnitude is any property that can be measured of a part of the space it occupies and the extension; what was done with the objective of a numerical measurement, through variables, the application of analysis techniques to know part of the reality or set of knowledge generated through the research, looking not only for concrete answers to the specific objectives of the research, but to conceptions or systems that try to explain reality under certain predetermined conditions. When we speak of analysis, we also refer to the use of a series of procedures or steps that try to make sense of the information, as part of an analytical task that must preserve its textual condition. The data that support the information about reality, imply a conceptual elaboration of that information and a way of expressing it that makes possible its preservation and communication.

The level of research is descriptive, since its purpose is to describe situations, managing to measure and evaluate aspects that are related to the object of study. In this sense, organizational aspects are described in order to optimize the processes according to the results or data obtained from the analysis and the current situation. It is a field design, given that situations can be explored, described or interpreted directly from reality, in order to seek effective solutions. It is a work supported by a documentary review, since it is oriented in a systematic, rigorous and rational process of data collection and information analysis.

Foundation and structure of the proposal

\section{A. Determination of the Variables}

It begins by analyzing the operation of the Automatic Power marine lantern with RETROLEDAM-6flasherasshowninillustration [16].

\section{Among the main characteristics are:}

- Provides a $360^{\circ}$ light signal

- 255 factory programmed codes and a user programmable position.

- 15 factory programmed LED intensity levels and one level is user programmable.

- Detection of short / open LEDs and protection of the flashing light. 
- Adjustable photocell thresholds for Day / Night.

- Adjustable thresholds of solar charge.

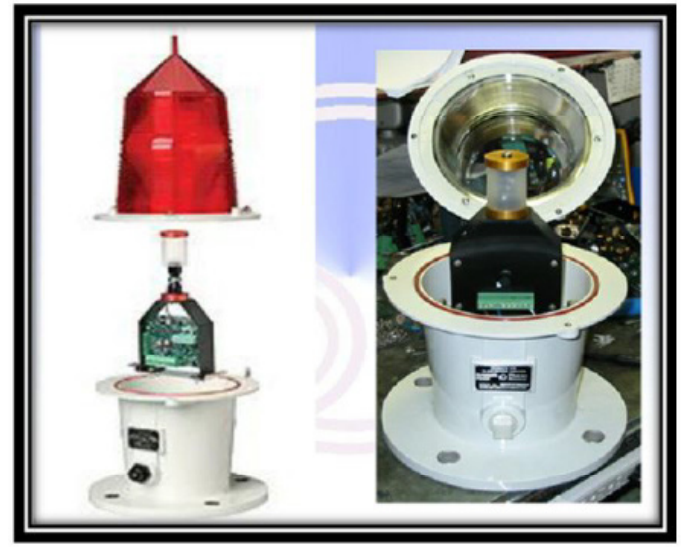

Figure 1. FA-246 marine lantern

Illustration 2 represents the different connections of the variables to be monitored, a "X2" connector is observed with inputs numbered from 1 to 10 where input 1 connects the positive terminal of the solar panel, input 7 connects the positive terminal of the "battery" power supply and in turn, at inputs 8 and 9 the negative terminals of both the solar panel and the battery are connected. [16].

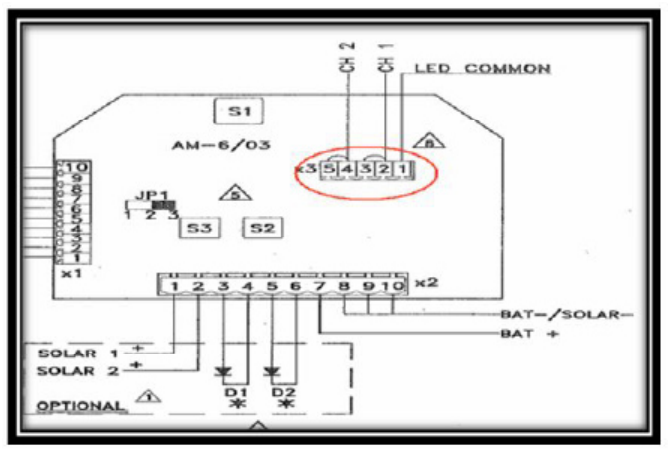

Figure 2. Schematic flashing card

Connector "X3" shows the connection of the array of LEDs, which is made up of two channels to which two LEDs are connected in series, and connector number 1 connects the common of the two channels. It should be clarified that figure 4 shows the alternative connection mode "M1" that provides a high current range, but in this project the "M2" configuration is used, which is the low current range, in which channels 1 and 2 are connected to terminals 2 and 3 respectively [18].

With the knob switch "S1" the current values that supply the LEDs are modified and with the switches "S3" and "S2" the flashing characteristics are modified, which form a two-digit hexadecimal number.

These independent inputs allowed taking the readings of the voltage variations of both the solar panel and the battery to monitor the electrical system.

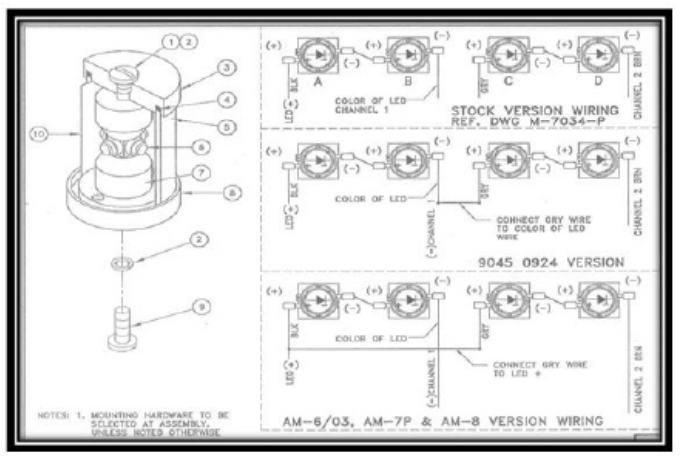

Figure 3. Arrangement of LEDs.

Figure 3 shows the configuration of the LED aFigure 3 shows the configuration of the LED array, which is controlled by an electronic card that can detect any short or open circuit condition caused by an LED in the array and can take appropriate action to protect itself. Additionally, the card can be configured from the factory to issue an LED failure alert [19].

The electronic flash card is configured with a flash period consisting of 0.8 seconds on at $6.7 \mathrm{~V}, 1.2$ seconds off at $0 \mathrm{~V}, 0.8$ seconds on $6.7 \mathrm{~V}, 1.2$ seconds off at $0 \mathrm{~V}, 0,8$ seconds on at $6.7 \mathrm{~V}, 7.2$ seconds off at $0 \mathrm{~V}$, for a period equal to 12 seconds. In order to determine the correct operation of the lamp, an analysis of the behavior of the voltages was performed at the common point of the LED's arrangement at the time the lamp was on and with all its 
LEDs in correct operation. With which it was possible to determine that when energizing the lamp after a lapse of time ( 2 hours) of being off the first voltage that can be measured in the ignition cycle has a value of 6.7V [20].

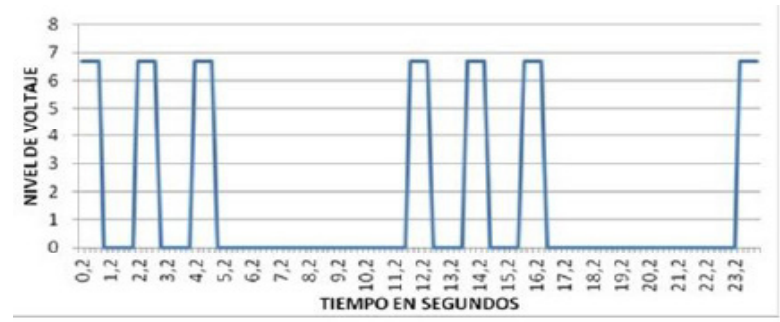

Figure 4. Flash period correct operation.

This voltage $(6.7 \mathrm{~V})$ increases by $20 \mathrm{mV}$ each time the cycle is repeated, reaching a maximum voltage of $7.8 \mathrm{~V}$, at which time the voltage begins to decrease until it stabilizes at $6.7 \mathrm{~V}$, voltage is maintained around 12 hours, lamp working time. [16]

Figure 4 shows the behavior graph of the lamp voltage in normal operation.

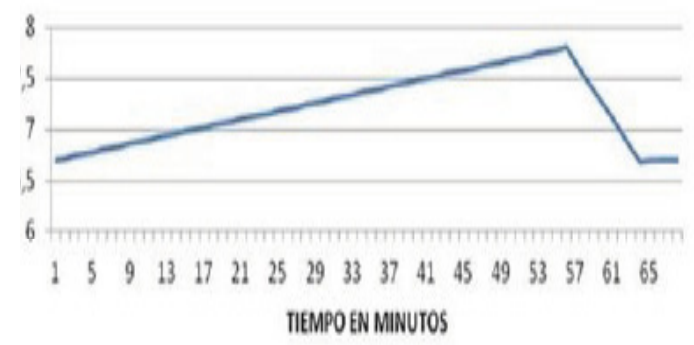

Figure 5. LED array behavior.

Subsequently, the operation of the lamp with 01 LED out of service was analyzed, the result obtained was: 0.8 seconds on $=0 \mathrm{~V} ; 1.2$ seconds off $=10.8 \mathrm{~V} ; 0.8$ seconds on $=0 \mathrm{~V} ; 1.2$ seconds off $=10.8 \mathrm{~V}$

; 0.8 seconds on $=0 \mathrm{~V} ; 1.2$ seconds off $=10.8 \mathrm{~V}$; 0.8 seconds on $=0 \mathrm{~V}$
$; 7.2$ seconds off $=10.8 \mathrm{~V}$. This same operation was performed with 02 and 03 LEDs's out of service, yielding the same results as shown in illustration 6 [17].

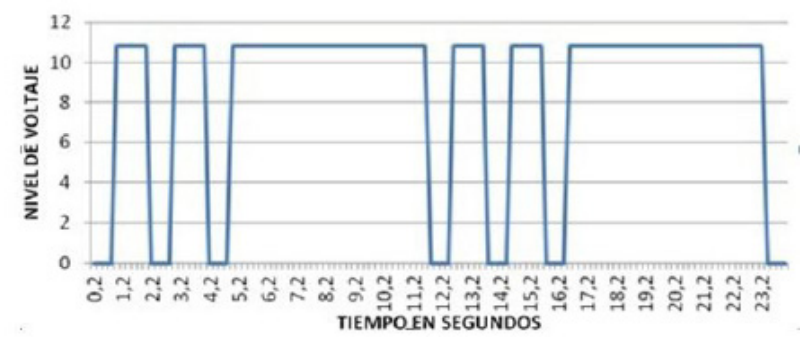

Figure 6. Flash periods with faulty LEDs.

This operation was performed with 02 LEDs that were out of service, yielding the same results as the previous test. It was determined that the flash card uses reverse logic to protect the circuit. The beacons use two types of solar panels: the first is a POWER UP brand: which supplies a VMP: 17.3VDC and an IMP: 1.2AMP; a VOC: 21.7VDC; one ISC: 1.3AMP. The second is BP SOLAR brand: VMP: 16.8VDC; IMP: 1.19AMP. To power the electronic elements, the buoy has a 6 load cell battery that delivers [18].

$12 \mathrm{~V}$ at $65 \mathrm{Ah}$. The flash card has a built-in solar panel controller to charge batteries.

\section{B. Stage of information acquisition}

For the acquisition of variables an interface was designed, which is composed of a control unit in charge of processing the variables that are sent to the communication stage composed of an RF modem.

The interface hardware for measurement of variables fulfills five fundamental functions:

a) Measurement of battery voltage level

b) Measurement of the voltage level of the solar panel output

c) Measurement of lamp performance. 
d) Acquisition of the buoy position information through the GPS module.

e) Declaration of operating alerts to the base station.

Each of these variables and alerts are sent to the transmission equipment ordered in a data frame. This is outlined in illustration 7.

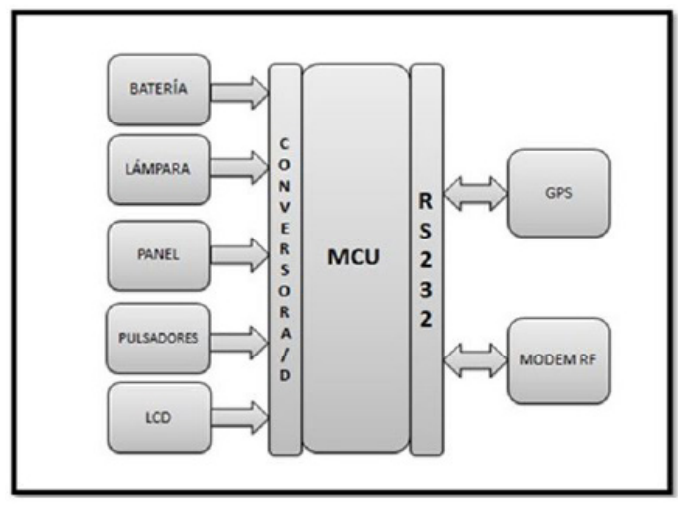

Figure 7. Interface diagram / Variable reading

\section{Stage of Communication.}

In this stage, a wireless link is established between the base station and the terminal points that are located inside the beacon at the top of the beacon.

The information from terminal number 2 which is furthest from the exchange reaches it through terminal number 1 , which upon receiving the information verifies the destination ID, as the information is not for it (terminal number 1) it forwards it to get you to your assigned destination [19].

When terminal number 1 forwards the information it received from terminal number 2 , this same information is received by the originating terminal (number 2), which checks the origin of the information and when verifying that it was the originator does not forward it.

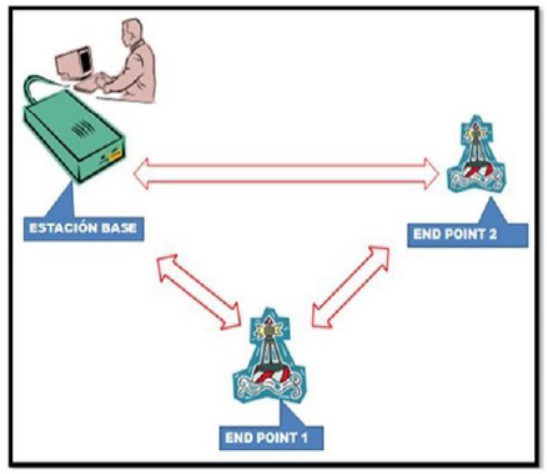

Figure 8. Wireless network diagram

As seen in Figure 8 and similarly when information is sent to terminal number 2 from the base station, said information arrives first at terminal number 1 , which collates it detecting that it is not for it and forwards it until reaching the terminal number 2. In this way it is possible to establish communications between each of the plant's terminals.

\section{Human-machine interface.}

It shows the information provided by the communication stage; To see this information it was necessary to adapt the received signals to the PC output device. The design begins by elaborating a general block, which is exposed in illustration 9, which integrates each and every one of the necessary elements within each terminal node. It should be noted that the base station only had the RF modem, since no samples are taken at this site, only information is received and transmitted via the RS232 port to the PC. [20].

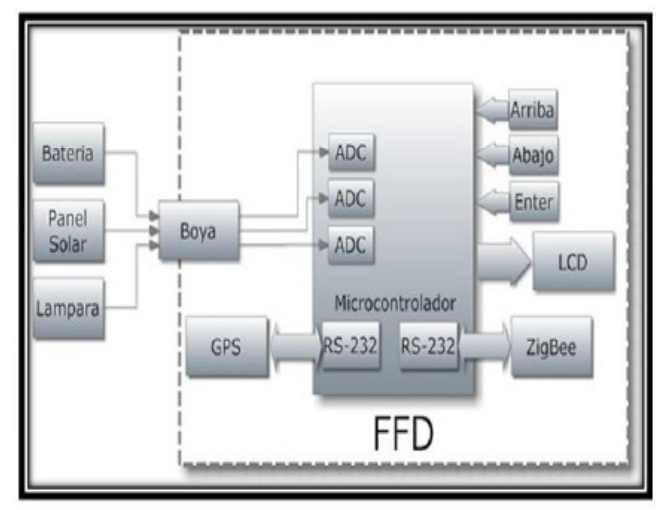


Figure 9. Block diagram.

In order to solve the problem that occurs when a buoy disengages from its dead weight and remains adrift, it is decided to use a device that determines the position of the buoy, for which high data transmission speed is not required and from which, additionally, the time and date can be extracted. [21]

For this application, the accuracy of the horizontal position is not a determining factor considering that a tolerance area is configured due to the displacement of the buoy due to the fact that it is tied to a dead weight through a chain. We wanted this device to use a serial communication protocol and also have small dimensions due to the limited space available inside the lantern.

Likewise, a liquid crystal display was implemented which will be connected to a control unit through a digital port, the above in order to carry out routine checks on site and configure the reference position in case the buoy is transferred to another place. This device only requires two lines of 16 characters each [22].

To configure the control unit at the site where the buoy is installed, 03 pushbuttons are implemented, for which 3 available digital ports are required on the control unit. Normal routing was performed for the PCB design, because the devices do not work with data at high speeds, therefore, it is unlikely that considerable parasitic capacitances will form. Because high current values are not used, the tracks are designed with the suggested standard width.

After analyzing the devices that would be mounted on the PCB, it was found that the GPS device works with $3 \mathrm{~V}$ to $3.6 \mathrm{~V}$ logic, and communicates through the RS-232 port with OV to $3 \mathrm{~V}$ logic and needs to receive signals on that same range of voltages. The rest of the devices work at $5 \mathrm{~V}$, taking this criterion into account, initially it was thought to implement a level converter inside the PCB so that the signals that the MCU sends to the GPS would go from $5 \mathrm{~V}$ to $3.6 \mathrm{~V}$, which is the logic that uses GPS. Conversely, the signals sent by the GPS would also be converted to $5 \mathrm{~V}$ to send to the MCU [23].

Then it was established that the micro controller can work without problem with a 3.3V logic, so it is decided that the entire integrated would be working at $3.3 \mathrm{~V}$. The MCU programming is done at $5 \mathrm{~V}$, taking into account that the rest of the interface elements work with $3.3 \mathrm{~V}$, a Jumper is implemented that isolates the circuit at the time of programming in order to avoid breakdowns in the other devices.

\section{E. Microcontroller Program.}

The MUC algorithm is intended to digitize analog viables, capture digital GPS data, and select data to be sent through the modem. It also sorts the data of the variables in the frames that are sent and identifies the frames that it receives, verifying if it forwards or omits them.

After initializing the program, the variables to be used are declared, the LCD and the analogdigital converters to be used are initialized, then it is questioned if it is in the "MENU" mode, if so, it checks whether "DOWN" has been pressed and it decreases a position in the menu, if it is "UP", it goes up a position in the menu if you press "ENTER", it executes the menu function in which it is at the moment and goes back to verify if it is in "MENU" mode or "PC".

When it is in "PC" mode, it verifies if the time that has been configured to send the status reports has passed, which is 120 seconds, if so, it executes the functions: read GPS, read battery voltage, read battery voltage lamp and read voltage from solar panel. Then, it sends 
the information of the variables in the frames configured for this purpose.

Then it questions if there are active alerts, it reviews those alert conditions and verifies if there is a need to send them, if so, it executes the alert sending function and proceeds to verify if information arrived from the modem. When it receives data from the modem, it proceeds to read that data. If the data frame is of request type, it verifies if it corresponds to the device, when it does not correspond it forwards the complete data, when the data corresponds to the device it executes the function of sending the requested information frame.

Soon if the data frame is of the configuration type, if so, it verifies if it corresponds to the device ID and proceeds to configure the device with the information received. Otherwise, it forwards the frame as it receives it. Then it verifies if the information received is of an alert type and, if so, it resends the information as it is received and continues verifying if any button was pressed and returns to the system startup.

\section{F. Frame Configuration}

The data frames are configured as follows:

- Information request frame (Request): This frame is sent from the control center to a specific terminal. The frame starts with the symbol "\$" then the letter indicating the type of frame for this case "R" followed by the identification (ID) of the destination terminal. All frames end with CR (Carrier Return - 0xOD) and LF (Line Feed - 0xOA)

$$
\text { \$-R-ID-;+CR+LF Ej: \$R02;+CR+LF }
$$

The request frame is used to request a terminal for the information of its variables at any time.
- Alert frames: This frame is identified with the letter " $E$ " after the " $\$$ " sign that identifies the beginning of all frames. Contrary to the previous frame, the assigned ID is the ID of the device that sends the information. It is followed by the variable that is generating the alert followed by the time in UTC format and then the value of the variable that for the example below is the latitude in decimal degrees and minutes followed by a letter of orientation which in the case of the example is the "N" North.

Example:

$$
\text { \$E01LAT,184950,10,58.046,N;+CR+LF }
$$

Alert frames are generated when the value of any of the variables goes outside the stipulated range, an alert frame is sent, immediately the MUC detects an out of range variable and continues to send it every time it sends the information frames for this project they were configured every 120 seconds.

- Configuration frame: Like all frames it starts with the character " \$" followed by the character that identifies the type of frame, in this case " $C$ ", it is followed by the ID of the device that sends the information, followed by the latitude in degrees and decimal minutes with their respective orientation, in this case "N". Then the length also in degrees and decimal minutes and its orientation character "W". Then the voltage of the lamp consisting of two integers and one decimal, then the battery voltage also with two integers and one decimal, followed by the voltage of the photovoltaic panel also consisting of two integers and one decimal and finally a character to enable (1) or disable (2) alerts.

Example:

$\$ C 01,10,58.044, N, 74,48.389, W, 11.8,10.4,11.0,1 ;+C R+L F$ 
With the configuration frames, the limit values of the variables to be measured are assigned.

- Information frames: three types of information frames were made and all start with the character " $\$$ " followed by the character that identifies the type of frame "A1", "A2" and "A3". Then the "ID" of the originating terminal. The three frames deliver different information.

$\$ A 101,000105,11,00.141, N, 074,48.313, W, 01.0 ;+C R+L F$

The information frame "A1" has the time in UTC format, the position indicated by the GPS with latitude in degrees and decimal minutes with orientation character, longitude also in degrees and decimal minutes with orientation character and the compound lamp voltage by two whole numbers and one decimal.

\section{A201,11,01.042,N,074,48.380,W,13.8,12.2;+CR+ LF}

The information frame "A2" has the position with which it was configured with latitude in degrees and decimal minutes with orientation character, longitude also in degrees and decimal minutes with orientation character, the voltage and the battery of the panel each composed of two whole numbers and one decimal.

$\$ A 301,11,01 \cdot 042, N, 074,48 \cdot 380, W, 09 \cdot 0,11 \cdot 3,12.0 ;+C R+L F$

The information frame " $\mathrm{A} 3$ " has configured the reference position made up of latitude and longitude, both in decimal degrees and minutes and with their respective orientation characters. Also the reference voltage of the lamp, battery and solar panel.

\section{Conclusions}

An interface with a PIC18F2550 MCU was implemented, which took advantage of its pins with A / D converters and its ability to establish communication through the RS232 protocol.
As I am registered in the tests that were carried out, a low error in the measurements made can be determined.

Afterconducting an analysis of newtechnologies to establish wireless communications, the ZIGBEE / IEEE 802.15.4 technology and specifically the RF Xbee-Pro PKG modem were selected demonstrating the feasibility of making the GPRS technology change; since it meets the required characteristics and works properly in the environmental conditions of the Cartagena bay. The implementation of a NETWORK is achieved with which communication is established between the terminals and the control center in which it is guaranteed that if a terminal transmits information to the central and does not reach it directly, this information can reach the central to through a terminal that is closer to the central.

\section{References}

[1] C. Amador Hooker y Y. Ariza Hernández, "El puerto marítimo de Cartagena y su importancia en el desarrrollo económico de la región", trabajo de fin de grado, Universidad San Buenaventura. Cartagena de Indias, 2018

[2] S. Andrade y E. Trujillo, "Diseño e implementación de un prototipo para realizar mediciones remotas de intensidad de señal recibida por un terminal móvil utilizando tecnología GSM. Quito", 2010. [En línea]. Disponible en: https://bibdigital.epn.edu.ec/ handle $/ 15000 / 2320$ ?locale $=$ en

[3] J. J. Granada-Torres, A. M. Cárdenas-Soto, y N. Guerrero-González, "Redes ópticas elásticas: un nuevo paradigma en las futuras redes de telecomunicaciones", Respuestas, vol. 20, n. ${ }^{\circ}$ 2, pp. 6-22, jul. 2015

[4] H. Zárate-Ceballos y J.E. Ortiz-Triviño, "Simulación de redes inalámbricas en NS-2", 
Respuestas, vol. 20, n. ${ }^{\circ}$ 1, pp. 38-50, ene. 2015

[5] M. O. Amarillo Rojas y L. C. Trujillo Arboleda, "Simulación de Redes de Sensores Inalámbricos: un Modelo Energético a Nivel de Nodo-Sensor Bajo las Especificaciones Ieee 802.15.4tm y Zigbee". Publ. investig, vol. 9, pp. 13 - 24, oct. 2015

[6] Equipo de Expertos. "Ciencia y Tecnología Universidad Internacional de Valencia", 2018. [En línea]. Disponible en: https://www. universidadviu.com/radiofrecuencia-que-esaplicaciones/

[7] R. Lugo-Villalba y E. Leal, "Análisis para la implementación de celdas de combustible en el sistema de propulsión ARC Arturus", Derrotero. 4, 119 p, 2017. Disponible en https:// issuu.com/revistaderroterol

[8] A. Flores, F. Guerra y R. Peralta, "Diseño de una plataforma para monitorear y controlar tráfico vehicular usando interfaces inalámbricas y GPRS Cataluña”, 2008. [En línea]. Disponible en:https://es.slideshare.net/ucsp/diseno-deuna-plataforma-para-monitorear-y-controlarel-trafico-vehicular-usando-interfacesinalambricas-y-gprs

[9] Y.E. Estevez-Mendoza, B. Medina-Delgado, y L.L. Camargo-Ariza, "Automodulación de fase en redes ópticas pasivas de próxima generación, utilizando modulación por desplazamiento cuaternario de fase", Respuestas, vol. 22, n. ${ }^{\circ}$, pp. 37 - 47, ene. 2017

[10] Electropartes S.A,“Fresscale Semiconducto". [En línea]. Disponible en: http://www. electrocomponentes.com/articulos/ diciembre06/zigbee.html. [Accedido 30 de mayo de 2018]

[11] Ingeniería MCI Ltda, "Guía del usuario XBEE Series 1. Providencia, Santiago, Chile", 2008. [En línea]. Disponible en: https://
www.mcielectronics.cl/website_MCI/static/ documents/XBee_Guia_Usuario.pdf

[12] P. Lieberwirth, "Redes inalámbricas para las fábricas del futuro", 2017. [En línea]. Disponible en: https://www.interempresas.net/Electronica/ Articulos/204038-Redes-inalambricas-paralas-fabricas-del-futuro.html

[13] P.J.R. Hechavarría-Hernández, A. CordovésGarcía, y M. García-Pérez, "Sistema para el cálculo de redes de acueducto", Respuestas, vol. 6 , n. ${ }^{\circ}$ 1, pp. 3-11, jun. 2016

[14] C. Moreno y L. Corrales, "Construcción de una red ZIGBEE prototipo para la adquisición de datos desde transmisores de corriente de dos hilos", trabajo de fin de grado, Escuela Politécnica Nacional, Ecucador 2009.

[15] J. Tomé, "Diseño de módulos ZIGBEE de bajo costo", 2006. [En línea]. Disponible en: https:// upcommons.upc.edu/handle/2099.1/3581

[16] Meteorcomm, "Productos de Ayudas a la Aeronavegacion - Linternas Marinas FA249LED. Houston, Texas: Form $\mathrm{N}^{\circ} 6310$ 1397SP.”, 2009. [En línea]. Disponible en: http://www.meteorcomm.com.ar/categoria. php?id_subcategoria $=67$

[17] J.L. Ramón Valencia, J.A. Ramón Valencia, y J.O. Maldonado Bautista, "Software de simulación para el diseño de reactores de lodos activados", Revista Colombiana de Tecnologías de Avanzada, vol. 2, no. 28, pp. 77-81, 2017.

[18] C.L. Corzo-Ruiz, D.A. Velazco-Capacho, "Control automático de microclima en invernadero para secado eficiente de granos de cacao", Revista Colombiana de Tecnologías de Avanzada, vol. 2, no. 32, pp. 104-108, 2018

[19] A. Cantillo Maldonado, O. Gualdron Guerrero, y J. Ortiz Sandoval, "Procesamiento de señales EMG en un sistema de embebido para el 
26

control neuronal de un brazo robótico". Revista Colombiana de Tecnologías de Avanzada, vol. 2, no. 32, pp. 139-147, 2018

[20] J.A Toscano, M.I. Cabellos Martínez y J.G. García Rincón, "Consumo de energía eléctrica en diferentes viviendas de la en la ciudad de Ocaña, Norte de Santander, Revista Colombiana de Tecnologías de Avanzada, vol. 1, no. 29, pp. 42-46, 2017

[21] C. Rivera-Ordoñez, J. J. Santiago, y J. FerreiraJaimes, "Reconocimiento de caracteres por medio de una red neuronal artificial", Respuestas, vol. 14, n. ${ }^{\circ}$ 1, pp. 30-39, may 2016

[22] C.A Vera Romero, J.E Barbosa Jaimes, D.C Pabón González, "Tecnología ZigBee estudio de las características de la capa física", Scientia Et Technica, vol. 22, no. 3, pp. 238245, septiembre, 2017

[23] J.G Chacón Rangel, A.S. Florez Fuentes y J.E Rodriguez Fernandez, "Clasificador difuso neuronal aplicado a casos de datos sintéticos", Mundo Fesc, vol. 5, n. ${ }^{\circ}$ 9, pp. 6-13, dic. 2015 